\title{
Spatial heterogeneity of nutrients in the Baltic Proper, Baltic Sea
}

\author{
Lars Rahm*, Åsa Danielsson \\ Department of Water and Environmental Studies, \\ Linköping University, \\ SE-581 83 Linköping, Sweden
}

Originally Published in Estuarine, Coastal and Shelf Science: 73, (1-2), 268-278, 2007. http://dx.doi.org/10.1016/j.ecss.2007.01.009

* Corresponding author.

E-mail address: larra@tema.liu.se. 


\section{ABSTRACT}

The Baltic Proper shows many signs of eutrophication. Nutrient changes over time have been discernable, and also within the Sea there are large spatial patterns. Present study analyses the spatial patterns of dissolved inorganic nitrogen and phosphorus as well as dissolved silicate (DSi) in the euphotic zone for the period 1990-2001. The focus is on the spatial heterogeneity with the aim to identify areas significantly different from the overall mean.

Three regions are clearly discernible, the interior, the western and the eastern coastal zones. This is further complicated by the Gulfs of Finland and Riga with distinct different behaviour compared to the other ones. While the coastal zones are re-supplied by their terrestrial sources, the exchange with the interior is limited by geophysical constraints. The western border shows permanently high DSi but low DIN and DIP concentrations. The riverine loads of DIN, DIP and DSi are low but a large transport of DSi probably takes place from the Bothnian Sea to the Kattegat along the western coast with only minor retention. The eastern region, on the other hand, is characterised by both high nutrient loads and high production. These spatial patterns agree well with a conceptual model where the spring bloom leads to an interior generally low in DIN. This favours N-fixating cyanobacteria blooms at the expense of diatoms. This view is supported by decreasing DIP concentrations but unaffected DSi levels. The spatial patterns observed well reflect the riverine nutrient loads. This should be regarded in future remedy plans for the eutrophic Baltic Sea. The terrestrial load can have very different impacts on the ecosystems depending on which coastal section is involved.

Keywords: dissolved silica; inorganic nitrogen; inorganic phosphorus; probability mapping; riverine load; residual circulation; coastal-offshore exchange 


\section{INTRODUCTION}

Concern for the fate of the Baltic Sea has grown during the last decades as numerous signs of eutrophication have been found (Bonsdorff et al., 2001). Today, the Baltic Sea represents one of the most eutrophied coastal areas in the world (Cloern, 2001). Larsson et al. (1985) estimated an increase in phosphorous and nitrogen loads by a factor of eight and four, respectively, since the 1950s. These increased anthropogenic loads have gradually built up the nitrogen and phosphorus concentrations in the water mass (Nehring and Mattäus, 1991; Sandén and Rahm, 1993). Simultaneously, the dissolved silicate (DSi) concentrations are decreasing (Sandén et al., 1991; Papush and Danielsson, 2006). This is assumed to be a result of increased diatom production and deposition, which reduces the DSi stock in the water mass (Schelske et al., 1983; Conley et al., 1993). Increased terrestrial retention of DSi due to river regulation and associated changes in weathering of soil and bedrock has also occurred (Humborg et al., 2000). The riverine nitrogen and phosphorus loads and point sources have a distinct geographical pattern following population density as well as agricultural and industrial activities (Sweitzer et al., 1996). The atmospheric deposition of nitrogen compounds also shows a large-scale NW-SE gradient with the highest concentration in the south-eastern Baltic Proper (Granat, 2001) and this, for the same reason as for the riverine loads. Regional management goals to reduce the anthropogenic impact often treat the Baltic Sea as a homogenous entity with little consideration to its spatial structure. These properties are essential for the understanding of the processes governing the nutrient dynamics as the key processes operate on different spatial scales, exemplified by e.g. the patchy nature of phytoplankton growth, localised up-welling of nutrient-rich water from deeper layers, and large-scale current transports of nutrients between different areas.

Present study aims to characterise large-scale spatial patterns of nutrients in the surface layer of the Baltic proper (BP). This is the largest basin of the Baltic Sea and is highly affected by eutrophication. The study is based on monitoring data. The monitoring activity has increased substantially since 1990 allowing the spatial patterns to be investigated in a better way than before. The results of this study will be an identification of areas with significantly higher respectively lower concentrations than the overall mean. Combined with nutrient load data and large-scale transports, this information will shed light on the underlying processes governing the large-scale silicate but also nitrogen and phosphorus patterns. This may facilitate the attempts to optimize future remedy actions.

\section{MATERIALS AND METHODS}

\subsection{Study area}

The Baltic Sea is located in the northern Europe (Fig. 1). It has shallow and narrow connections to the Kattegat and the North Sea which lead to a limited water exchange. This results in a brackish Sea. The largest basin, the Baltic Proper, is an area with a well-mixed surface layer and a salinity stratified deeper layer. They are separated by a strong halocline. This limits both the rate of recycling of nutrients from the deeper layers and the supply of oxygen to them (Pers and Rahm, 2000). On the other hand, this limited supply of oxygen leads to both hypoxia and denitrification and also facilitates the recycling of phosphate (Conley et al., 2002) and, to a certain amount, DSi, back to the water mass (Berner and Berner, 1996; Nixon et al., 1996). 


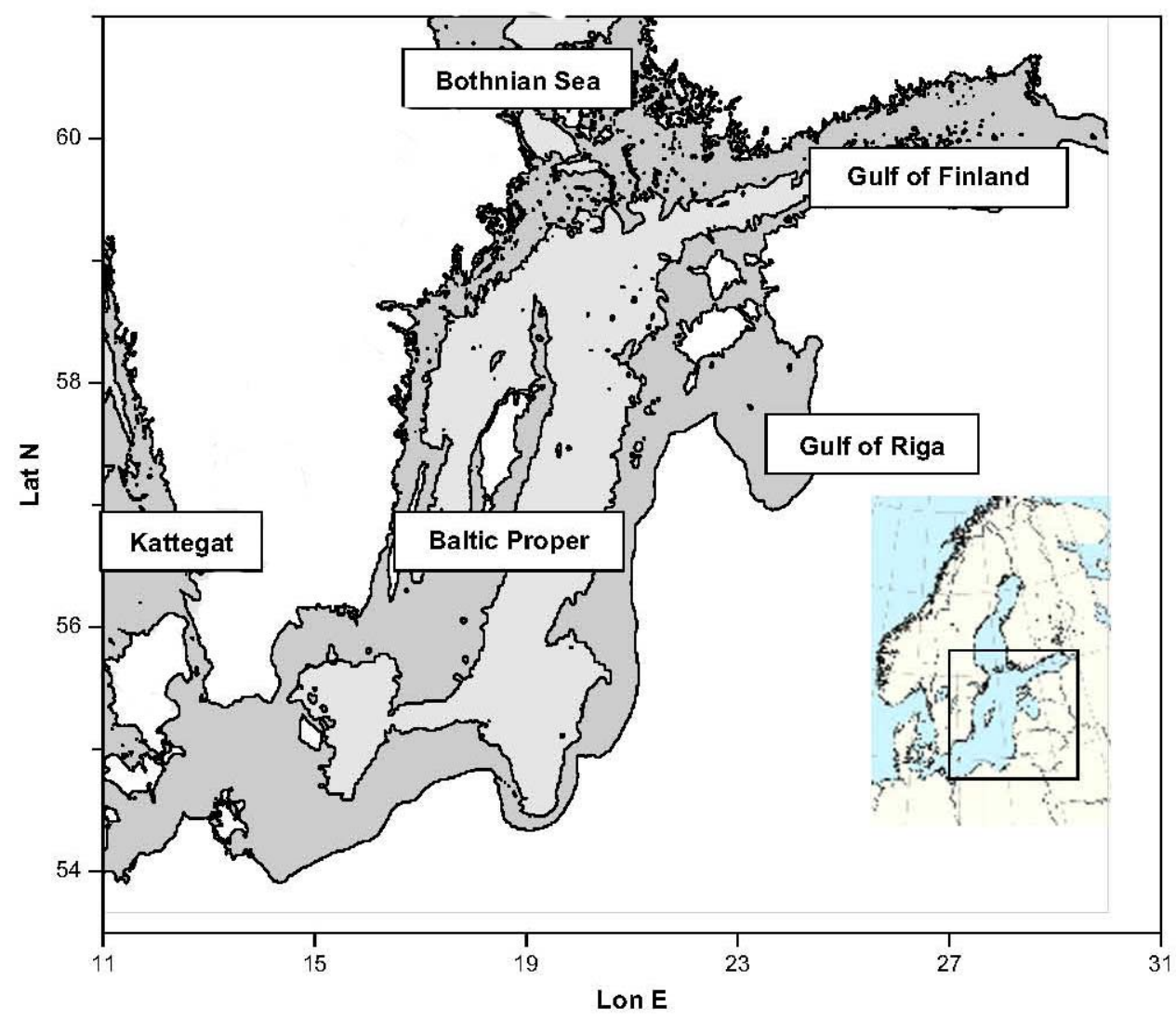

Fig. 1: Map over Baltic Proper with the major sea areas. The $60 \mathrm{~m}$ isobath is shown.

Trend tests have revealed increasing nitrate and phosphate concentrations in the water body during 1970-90 (Sandén and Rahm, 1993) as well as significantly decreasing DSi levels (Sandén et al., 1991). During the last decade these trends are, however, decreasing (Papush and Danielsson, 2006). Spatially, there is a north-south gradient in nitrogen and phosphorus loads with higher loads in the southern parts. These can be linked to the distribution of population, farming, industrial production, major rivers and point sources, hence, the major loads are found in the south-eastern parts (Sweitzer et al., 1996). The atmospheric deposition, corresponding to a third of the nitrogen load from rivers and point sources, shows a similar SE-NW pattern (Granat, 2001; Bartnicki et al., 2001). Sandén and Danielsson (1995) showed that the average nutrient concentrations in the major sub-basins of the BP are very similar irrespective of season. This is because the coastal zone is omitted in their analysis. DSi, on the other hand, is a weathering product with major sources in the Gulf of Bothnia, thus it will show a different distribution pattern.

\subsection{Data material}

Data were retrieved from the Baltic Environmental Database at Stockholm University (Sokolov et al., 1997). These include quality checked nutrient data from the marine monitoring programs of the riparian countries of the Baltic Sea, including hydrography and biochemistry. The riverine nutrient loads are based on the period 1971-1990 and data from the database NEST (http://www.mare.su.se/nest). This time period is chosen to harmonize with the model calculations by Wulff et al. (2001) as the latter is used in the discussion below. No dramatic changes have occurred during the last decade. In the present study, the immediately bioavailable DIN (dissolved inorganic nitrogen), DIP (dissolved inorganic phosphorus) and DSi are used to reflect the nutrient patterns. Salinity is included as a 
conservative tracer to indicate the origin of the water masses. Data are averaged over the upper 0-20 m, i.e. the euphotic zone, for the respective sampling event.

To handle seasonality in data, the years were divided into three periods November-March, April-June and July-October. By this, the seasonal cycle is resolved with high winter concentrations and decreasing levels during spring bloom, where after a successive restoring of the stocks occurs during autumn until the storage is refilled. Since the spring bloom sets off earlier in the southern parts than further north, the seasonal division may be slightly misleading, but the time lag is at most of the order of one month. The number of observations used for each nutrient is 8400,7000 and 9200 for the winter, spring and autumn, respectively, over the time period 1990-2001.

Satellite pictures were used to estimate the extension of the cyanobacteria blooms. These pictures have been compiled on a daily basis by M. Hansson (SMHI). A satellite carrying a spectroradiometer (MODIS) with a resolution of $0.5 \times 0.5 \mathrm{~km}$ has been used to identify cyanobacteria blooms each day during the summer season. The number of days with blooms is calculated for the time period 1997-2004. These data are primarily used in the Swedish algal monitoring program (year 2001 is lacking due to antenna problems).

\subsection{Probability mapping}

In the nutrient data set, some stations are visited more frequently than others. This will produce an unproportionally high weight for certain stations in common statistical analysis. Therefore, the method of probability mapping (Choynowski, 1959) was chosen as it takes into account the different number of observations per grid cell (Cressie and Read, 1985, 1989). A recent application of the method is found in Danielsson et al. (2004) dealing with nutrient distributions in Kattegat (Baltic Sea). The essence of this method is that it uses probabilities based on a probability (Poisson) distribution and not on the observations themselves. The mapping gives a statistical measure of spatial heterogeneity by testing the null hypothesis that all cells have statistically the same median value taking the different number of observations into account. Median is chosen to avoid skewed representation in certain regions, e.g. close to river mouths. A rejection of the hypothesis means that the frequency of concentrations above or below the overall median is either significantly higher or lower than expected. A lattice with grid cells of size $1^{\circ} \times 0.5^{\circ}$ (longitude $\mathrm{x}$ latitude) is used to aggregate stations into subareas, where all data within a grid cell are analysed as an ensemble. The chosen size of grid cell is a trade off between spatial resolution and observation frequency. Only cells with more than nine observations over the study period are used in order to minimise spurious results. Some cells will show a lack of data, especially during spring and autumn, due to the infrequent sampling.

\section{RESULTS}

The salinity concentration in the surface layer is in the range 6-8 PSU, with the highest salinities during winter and lowest during spring. Also this seasonality is reflected in the nutrient dynamics with typical seasonal patterns (Fig. 2). Note that this variation is more pronounced for DIN and DIP than for DSi. The DIN concentrations are in the range 0.1-8 $\mathrm{uM}$, the inorganic phosphorus concentrations are found in the interval 0.0-1.0 uM while the DSi concentrations are in the range 1-20 uM. 


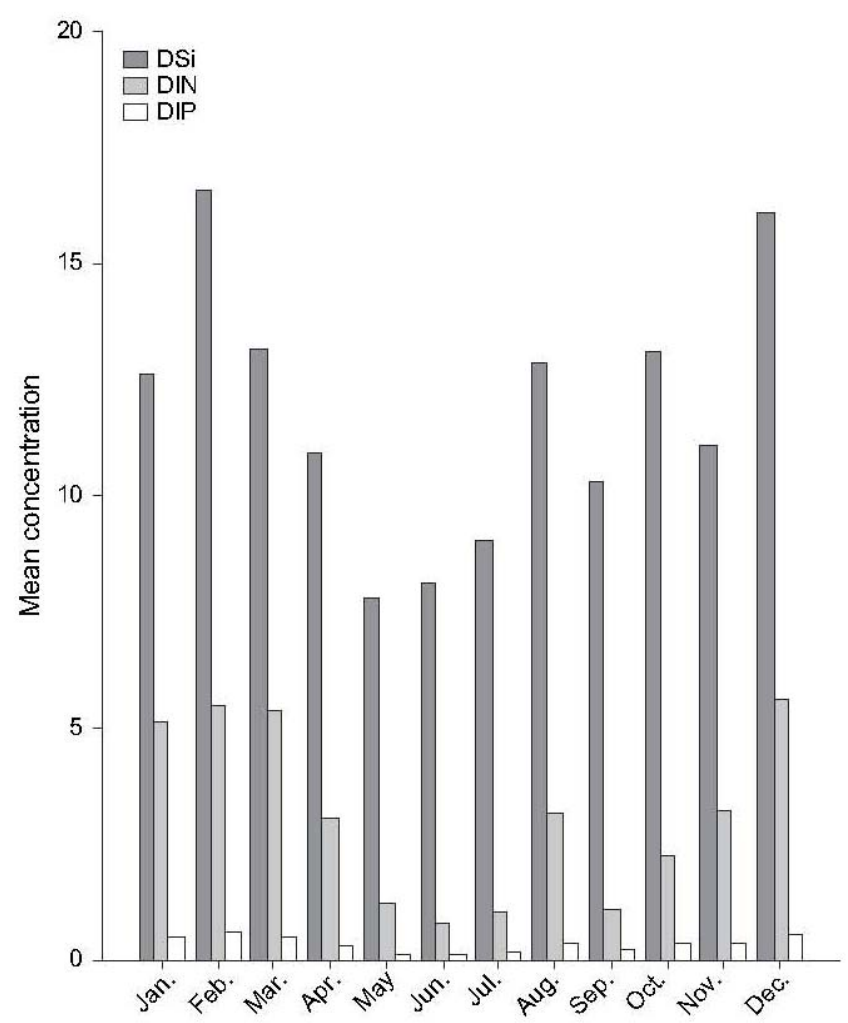

Fig. 2: Nutrient seasonal changes. Bar charts presenting monthly average concentrations of DIN and DSi [umol $l^{-1}$ ] as well as DIP [10 *umol $l^{-1}$ ]. The data represent the photic zone (0$20 \mathrm{~m}$ ) of the entire Baltic Proper for the time period 1990-2001.

\subsection{Salinity}

The salinity maps present the main hydrographical structures of the basin (Fig. 3a). In the interior, there are a large number of cells with salinities significantly higher than the overall median. Lower concentrations are found along the coasts with large freshwater discharge from rivers, in the Gulf of Riga (GoR), and to some extent in the Gulf of Finland (GoF). Overlaying this pattern is a marked north-south gradient, with higher concentrations in the south.

\subsection{Dissolved silica}

The DSi concentrations are significantly higher in the coastal zone along the western border than elsewhere (Fig. 3b). This high-concentration region reaches up into the southern part of the Bothnian Sea irrespective of season. The eastern part, including GoR and GoF, has significantly low concentrations. During spring, the concentration in the interior is significantly higher than the overall median. Later on, in the autumn, the conditions become more similar to the winter conditions with an interior close to the median but high concentrations in the southern parts.

\subsection{Dissolved inorganic nitrogen}

The DIN concentrations are generally lower in the interior than in the coastal areas (Fig. 3c). Significantly high concentrations are found, for all seasons, in the eastern and southern coastal areas and are further enhanced in the GoR. Significantly low concentrations are 
located to the interior and the GoF. During spring, cells with significantly high concentrations are reduced to only a few along the eastern coast close to major river outlets. At the same time, the number of cells with significantly low concentrations increases, especially in the interior. This structure remains during autumn although the interior generally approaches the overall median concentration.
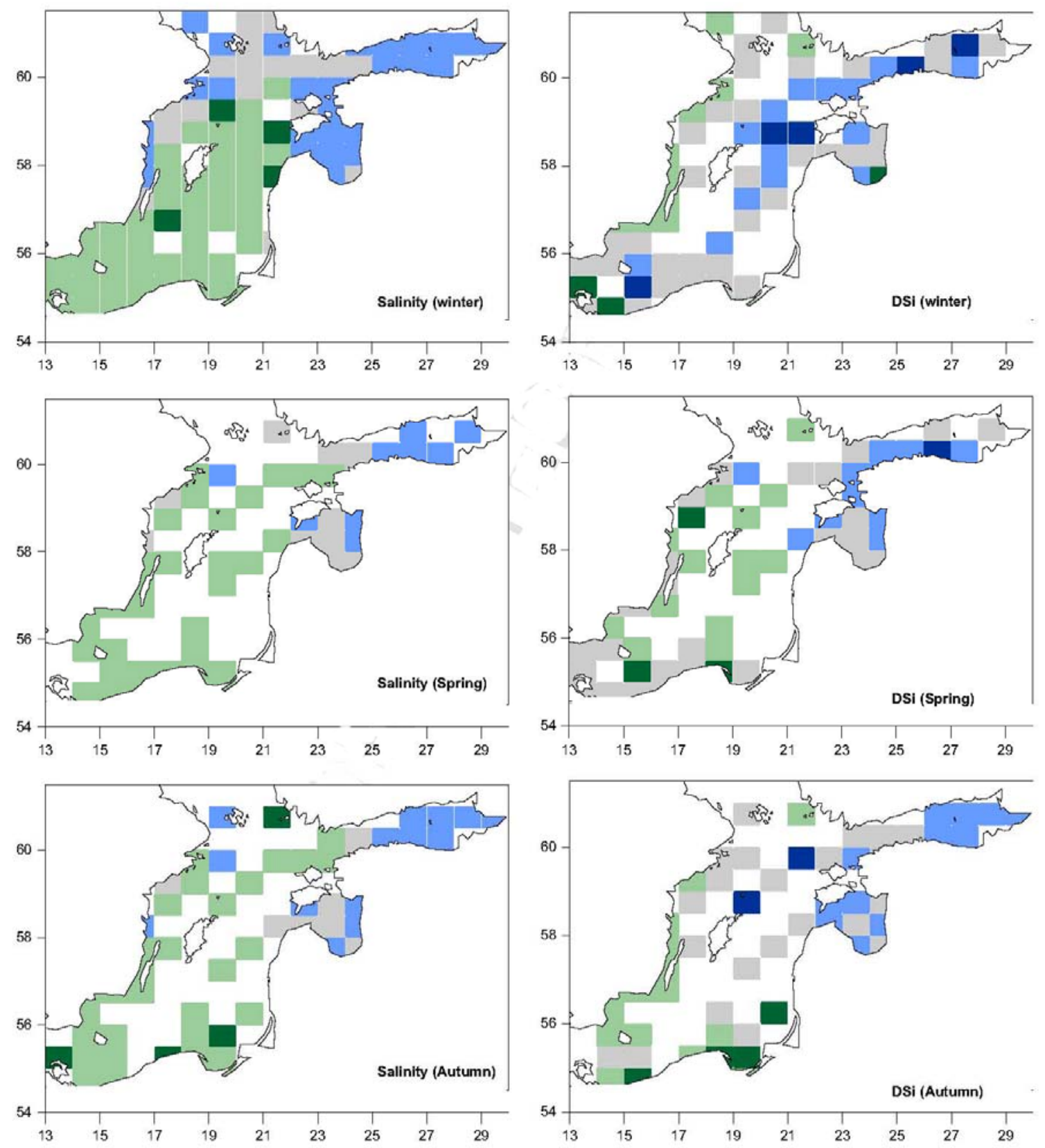

Fig. 3: Seasonal probability maps for (a) salinity, (b) DSi, (c) DIN and (d) DIP. Green denotes a cell with significantly higher concentrations and blue denotes a cell with significantly lower concentrations than the overall median (dark $=p<0.01$; light $=p<$ 0.05). Grey represents cells without sufficient number of observations (i.e. $<10$ ). 

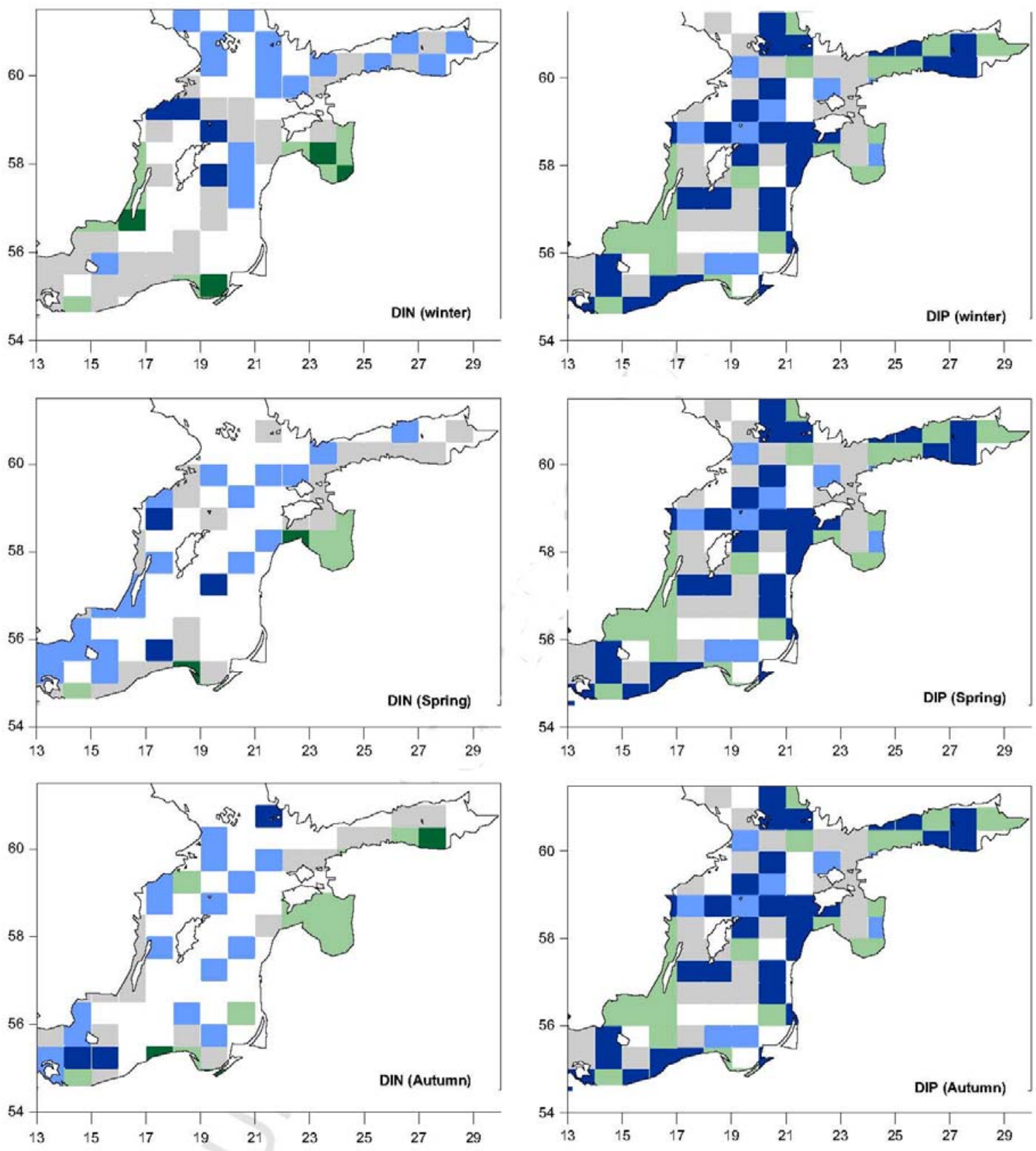

Fig. 3 cont'd

\subsection{Dissolved inorganic phosphorus}

The spatial pattern for DIP is less pronounced than for the other two nutrients. The interior is more or less homogenous during spring (Fig. 3d) while significantly low levels dominate during autumn and winter. In GoR and GoF, as well as along the western and southern coasts, significantly high levels are found during all seasons. The only exception is GoR during spring and the southern coast during winter. 


\subsection{Cyanobacteria blooms}

There is no clear trend in cyanobacteria blooms. The temporal extent of the blooms as well as their spatial patterns varies largely between years. The number of cyanobacteria bloom days reaches up to 20 days per year at a single location (Fig. 4). In general, these pictures show an interior prone to cyanobacteria blooms, but generally unaffected coastal zones.

\section{DISCUSSION}

The numerous signs of eutrophication in the BP have lead to substantial remedy plans and actions. A majority of these actions have been focused on major point sources such as sewage treatment plants (HELCOM, 1998). With a large number of point sources remedied, the interest has successively shifted to the more diffuse leakage from agriculture and forestry (Stålnacke, 1996). Since the BP has been assumed nitrogen limited (Granéli et al., 1990), this has emphazised the reduction of nitrogen loads in favour of the phosphorus ones. However, it has also become obvious in later years that internal sources such as phosphorus leaking anoxic sediments (Conley et al., 2002) and N-fixating cyanobacteria (Bianchi et al., 2000; Rahm et al., 2000) play quantitatively important roles in the eutrophication process. The reason behind these somewhat contradictive perspectives is to a large degree the spatiotemporal differences in production limitation which partly have been analyzed in Boesch et al. (2005). The spring bloom is generally assumed nitrogen limited in the BP, the first phase

is based on diatoms when nutrient levels are initially high but its supply limited due to the build up of a seasonal thermoclime. It is followed by dinoflagellates, which have the competitive advantage of being able to get the necessary DIN in deeper layers and then bring it up to the then depleted photic zone. The bloom usually ends when the DIN stock is exhausted. The following bloom will be based on $\mathrm{N}$-fixation and the residual $\mathrm{P}$ stock, i.e. the production of cyanobacteria becomes $\mathrm{P}$ limited. Only a late autumn bloom, linked to a deepening thermocline, may again be $\mathrm{N}$ limited and in this case often based on diatoms. Note that the degradation of sedimenting organic matter may be connected to denitrification and thus loss of otherwise bioavailable N. It is obvious that during these conditions it is important to determine the governing mechanisms in the observed spatial patterns of nutrients.

\subsection{Hydrographical differences}

The residence time for salt is about a decade in the Baltic Proper (Wulff et al., 2001). This dampens the impact of both short-term variation in freshwater load and episodic large inflows of saline water. The salinity distribution in Fig. 3a agrees well with the general view of the Baltic Proper hydrography. Seasonally, there is a large variation with lower salinities during spring flood, higher concentrations during autumn and highest concentrations during winter when the freshwater discharge is low. The northern interior and the coastal parts have significantly lower salinities depending on the large freshwater export from both GoR and GoF ( $\sim 55 \%$ of the river discharge to BP; Wulff et al., 2001). The highest salinities are found in the south-western part as a result of the saltwater intrusion. Most of the motion and mixing in the area are atmospherically forced as is the residual anti-clockwise circulation (Palmén, 1930). This circulation transports saline water from the entrance at the Danish Straits northwards along the eastern border while more brackish water flows southward along the western border (Eilola and Stigebrandt, 1998). 

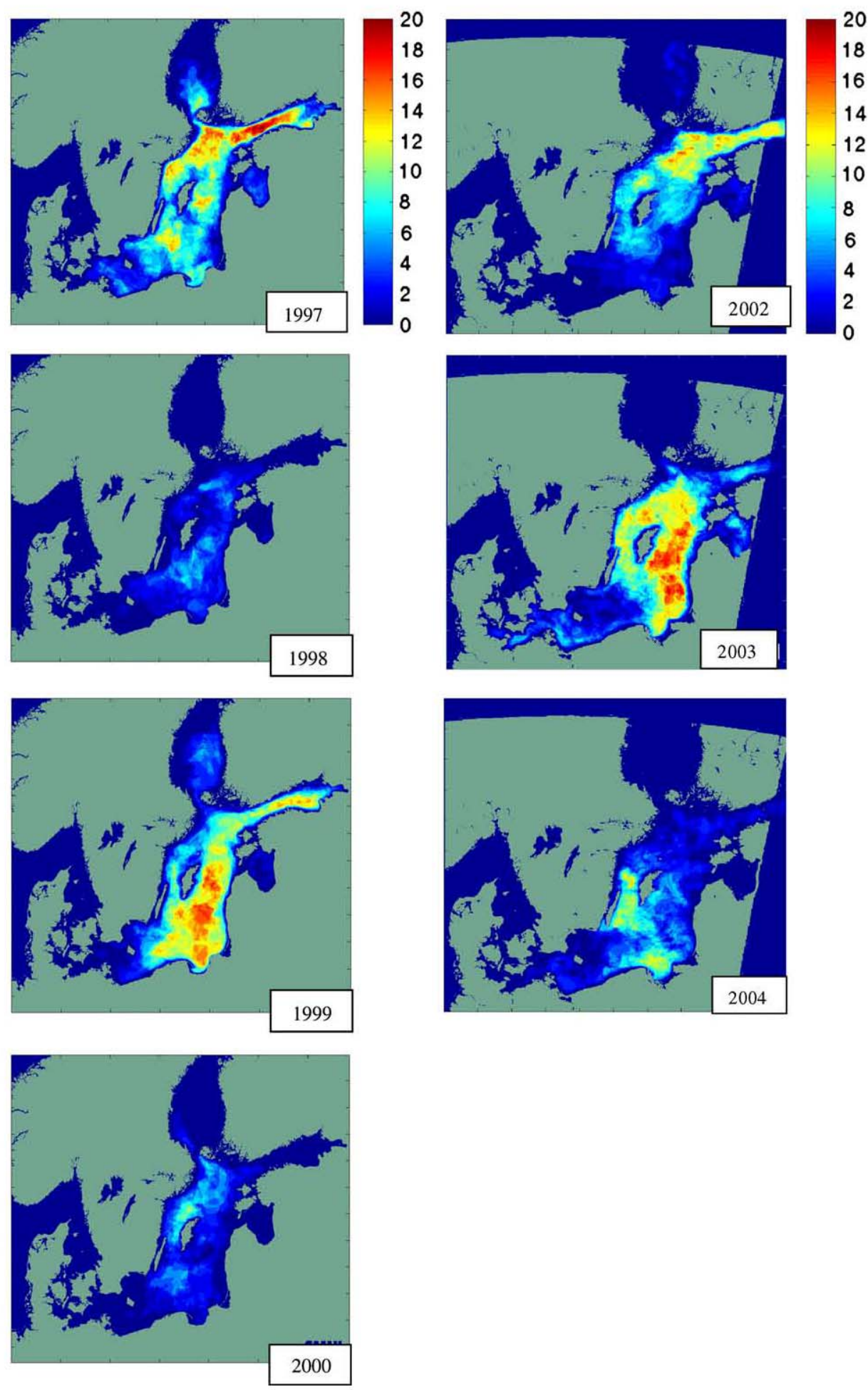

Fig.4 : Annual number of days with cyanobacteria blooms detected in the Baltic Sea. These are based on satellite images with a resolution of $0.5 \times 0.5 \mathrm{~km}$ (maps used with the kind permission of M. Hansson, SMHI). Two different projections are used. 


\subsection{DSi patterns and loads}

There is a clear seasonal pattern shown in the interior of the basin (Figs. 2, 3b). The shift in the interior from mainly a high to a low level area during autumn may be explained by the limited DSi supply during the growth season. The northern and eastern BP, together with GoR and GoF, remain low concentration areas during all seasons, while the DSi levels in the western and southern parts of the BP are significantly higher than the average (Fig. 3b). About half of the DSi load emanates from the eastern and southern coasts but only $9 \%$ from its western parts (Fig. 5).

But how can the western parts show significantly high levels? It is probably a result of the large supply of DSi from the Bothnian Sea ( 220 kton/yr; Wulff et al., 2001). This is to some degree associated with the spreading of juvenile freshwater (i.e. freshwater trapped by seasonal stratification) from the northern part to the interior. Eilola and Stigebrandt (1998) explain the initially fast spreading of this water to wind forcing during spring, a forcing that decreases during summer with more calm conditions (Jönsson et al., 2002). This suggests that also the DSi supply to the interior should decrease during the summer months.

Taking the residual circulation into account, it is reasonable to assume that the DSi from the Bothnian Sea is mainly transferred along the western border to the Kattegat. Assuming this, the retention along the western border should be in the order of the local nutrient load. In addition, the internal load is assumed negligible, as the recycling of silicate from the sediments is a slow process (Conley and Quigley, 1988). Also, it is notable that the eastern parts are characterised by frequently low DSi levels. Here the high DSi riverine load seems balanced by a high diatom production.

\subsection{DIN and DIP patterns and loads}

Both the DIN and DIP distributions are generally characterized by an interior with significantly low concentrations (Fig. 3c, d). The high DIN concentrations occur during the winter season along the western, southern and eastern coasts and in GoR and GoF reflecting the large riverine loads (Fig. 5). During spring, high concentrations are found along the southern coasts and in GoR, i.e. close to the major river mouths dominated by spring floods. During autumn, the DIN patterns adjust to the winter ones, while the DIP distribution seems to approach its winter conditions a little slower. The significantly high concentrations of DIP are also located along the coasts close to major point sources and rivers. The less distinct pattern of DIP has also been noticed in a similar study in the Kattegat, where it was attributed to the influence of internal sources including sediment fluxes (Danielsson et al., 2004). DIP has a high redox-controlled affinity to particles affecting its mobility (Conley et al., 2002). A consequence of the high mobility in combination with a long residence time is that its distribution less well reflects its spatially distributed sources and processes.

The atmospheric nitrogen deposition shows a NW-SE gradient over the BP but the long length scales involved cannot substantially change the picture given above. The atmospheric deposition of DSi and DIP is negligible. Also the DIN and DON export from the Gulf of Bothnia is negligible, representing only a few percent of the total load to BP (see budget model by Wulff et al., 2001). In fact, the corresponding inorganic and organic phosphorus loads are "negative", i.e. Bothnian Sea seems to import phosphorus from BP. The southern and eastern parts are, on the other hand, characterised by high loads from rivers and point sources (HELCOM, 1998; Grimvall and Stålnacke, 2001). In fact, almost all of the total 
terrestrial nitrogen load originates from the eastern parts. These results are supported by the total nitrogen and phosphorus loads presented for the May-October period by Stepanauskas et al. (2002). Regional attempts to decrease the total loads have led to some reductions during latter years, especially among the larger point sources (HELCOM, 1998). There has been a drastic decrease in fertiliser consumption, reduction in livestock and increases in sewage treatment capacity after the political changes in the eastern Baltic around 1990. Despite this, the nutrient loads have not decreased substantially (Löfgren et al., 1999). This is probably due to the large storage capacity in soil and sediments supporting a continuous long-term leakage (Stålnacke et al., 2003).

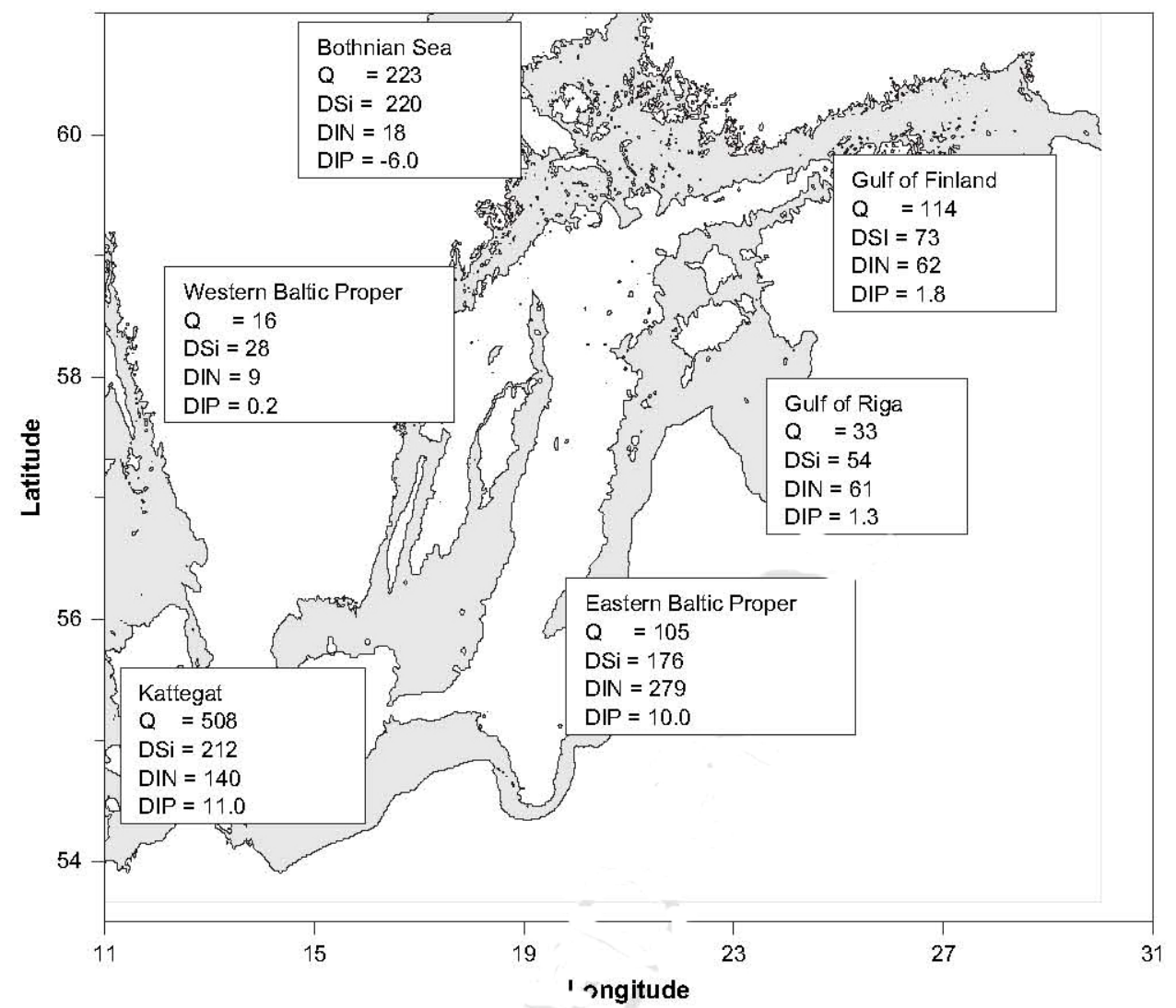

Fig. 5: Annual river discharge $Q\left(\mathrm{~km}^{3} \mathrm{yr}^{-1}\right)$ and loads of DSi, DIN and DIP (kton/yr) for the coastal sections of the Baltic Proper together with net import from the Bothnian Sea and net export to the Kattegat. The coastal sections include the eastern and western Baltic Proper as well as the Gulfs of Finland and Riga.

Diffuse export of river loads from the coastal zone to the interior should take several months following Okubo (1971). Voss et al. (2005a,b) have shown that land-based loads of DIN and PON (particulate organic nitrogen), in general, remain in the coastal zone. The nitrogen will either be denitrified or buried while the transport to the interior seems insignificant. Thus, the nutrient losses due to blooms in the interior should not be re-supplied on a time scale of a few months. This view is supported by the frequent occurrence of $\mathrm{N}$-fixating cyanobacteria blooms in the interior (Fig. 4; Finni et al., 2001). These should represent a substantial internal nitrogen source during the summer periods (Savchuk and Wulff, 1999; Savage, 2005). This source is of the same magnitude as the terrestrial load but seems to have large interannual variations (Rahm et al., 2000; Larsson et al., 2001). 
For the western part, the situation is different. The import of nitrogen from the Bothnian Sea is almost negligible (Wulff et al., 2001) compared to the net export of nitrogen (mostly organic nitrogen; ON) to the Kattegat ( 140 kton/yr; Wulff et al., 2001). Based on the same argumentation as for DSi, the ON export should represent a substantial sink of DIN. The source of this nitrogen seems to come from terrestrial sources, primary production (including cyanobacteria blooms) and up-welling from deeper nutrient-rich layers. The latter occurs frequently along the western coast due to prevailing wind directions (Gidhagen, 1987).

\subsection{Implications of asymmetry}

The spring bloom is mainly nitrogen limited (Grane'li et al., 1990) as discussed above. This bloom often leads to very low DIN but still substantial DIP concentrations in the euphotic zone (Granéli et al., 1990). Under sunny and calm conditions, this may cause intense Nfixating cyanobacteria blooms if the supply rate of primarily DIN to the interior is limited as we have all reasons to believe. The frequency and spatial extent of these blooms seem to increase with on going eutrophication. This shift in species succession, i.e. the growth of cyanobacteria at the expense of diatoms and other phytoplankton species, will have farreaching consequences for the nutrient stocks, carbon cycling, food web and consequently for the management of the Baltic Sea. This view is also put forward in Boesch et al. (2005).

High DSi supply from the Bothnian Sea and a similar export of DSi to Kattegat suggest a transfer of silicate through the western region. This transfer goes probably via a "coastal current"' along the western coast. Coastal currents are a common feature in the Baltic (see e.g. Håkansson et al., 1996; Dahl, 2006) and they are essential parts of the anti-clockwise circulation of the major Baltic basins. The geostrophy together with topography and freshwater supply governs the flow. A considerable amount of DON (Wulff et al., 2001) is probably exported to the Kattegat along this route.

The southern and eastern coastal areas receive high nutrient loads. Consequently, the prerequisites for high primary production, in general, seem fulfilled along these borders. Kahru et al. (1994) found an east-west asymmetry with few visible blooms in the southern and south-eastern parts of the BP and more frequent blooms along the western and northern borders. Present study shows an interior prone to cyanobacteria blooms, but generally unaffected coastal zones (Fig. 4). The interannual variation is largely due to a high sensitivity to solar radiation and wind mixing controlling the coastal-interior exchange. A consequence should be a generally limited diatom production in the interior despite good supply of DSi due to the lack of DIN. In contrast stands the eastern region which has a good supply of all nutriaents during the whole year.

\section{CONCLUSIONS}

Present study shows that there are statistically significant differences between the western and eastern coastal zones as well as the interior with regard to DIN, DIP and DSi. This suggests biogeochemically different domains separated by geophysical constraints (wind mixing, stratification and circulation) and nutrient loads. Further, at the eastern border the primary production is supported by high riverine and point source loads, while along the western border the riverine nutrient loads are limited. However, in the latter part, there seems to be a transport of Bothnian Sea water to Kattegat which is rich in DSi but low in DIP and DIN. Nutrient transports from the coasts to the interior seem less efficient which leads to repeated lack of DIN in the interior after the spring bloom while P still remains in useful 
concentrations, which facilitates a pronounced cyanobacteria bloom. On the other hand, the interior is continuously recharged with nutrients from internal sources, but they probably act on longer time scales than those which govern the growth period. These decadal monitoring data agree well with annual cumulative cyanobacteria blooms based on daily satellite pictures.

A merit of the statistical method used is that it gives quantitative measures based on spatial distribution of nutrients from the regional monitoring program "irrespective" of its varying spatio-temporal resolution. A conclusion for the future Baltic management is that the discussed spatial asymmetry and its causes should be considered in future plans to reduce the effect of eutrophication. Substantial changes in loading require huge regional economic investments why optimizations are necessary. The results above regarding the regional differences in external/internal loads and production suggest both a general decrease in $\mathrm{P}$ loads and a reduction in $\mathrm{N}$ loads with focus on the eastern parts. This should in the long run decrease the cyanobacteria blooms and intense phytoplankton blooms along the eastern Baltic coast. The present simplistic approach ignoring the various regional characteristics will be both counterproductive and expensive.

\section{ACKNOWLEDGEMENTS}

This work was financially supported by the European Commission (R\&D Priority Sustainable Marine Ecosystems contract EVK3-CT-2002-00069). The authors gratefully acknowledge three anonymous referees. The authors would also like to pay their gratitude to Martin Hansson (SMHI), who made available the compilation of daily blooms based on satellite monitoring by SMHI and the Baltic Algal Watch System (2002-2004) as well as the corresponding results from the EU-project HABES (1997-2000). We also acknowledge Miguel Rodriguez-Medina (SU) for support with the BED database, Alexander Sokolov and Fredrik Wulff (SU) for access to the NEST decision support system and the following monitoring organizations which have contributed to BED: FIMR, Finland; EMI, Estonia; Marine Monitoring Centre, Institute of Aquatic Ecology, Latvia; Lithuanian Maritime Safety Administration, Lithuania; Inst. of Meteorology and Water Management, Poland; Sea Fisheries Institute, Poland; Bundesamt für Seeschifffahrt und Hydrographie, Germany; NERC; Denmark; SMF, UMF, SMHI and Stockholm Vatten, Sweden.

\section{REFERENCES}

Bartnicki, J., Gusev, A., Pavlova, N., Ilyin, I., Lukewille, A., Barrett, K., 2001. Atmospheric supply of nitrogen, lead, cadmium, mercury and lindane to the Baltic Sea in 1997. EMEP Centres Joint Report for HELCOM, EMEP MSC-W Note 6/99, Norwegian Meteorological Institute, Oslo, Norway.

Berner, E.K., Berner, R.A., 1996. Global Environment: Water, Air and Geochemical Cycles. Prentice Hall, 376 p.

Bianchi, T.S., Engelhaupt, E., Westman, P., Andren, T., Rolff, C., Elmgren, R., 2000. Cyanobacterial blooms in the Baltic Sea: natural or human-induced? Limnology and Oceanography 45, 716-726.

Boesch, D., Heckey, R., O’Melia, C., Schindler, D., Seitzinger, S., 2005. Expert Evaluation of the Eutrophication of the Seas Surrounding Sweden. Swedish EPA. http://www.naturvardsverket.se/dokument/fororen/overgod/ eutro/expert.htm, 56 p.

Bonsdorff, E., Ro“nnberg, C., Aarnio, R., 2001. Some ecological properties in relation to eutrophication in the Baltic Sea. Hydrobiologia 475-476, 371-377.

Choynowski, M., 1959. Maps based on probabilities. Journal of the American Statistical Association 54, 385388.

Cloern, J., 2001. Our evolving conceptual model of the coastal eutrophication problem. Marine Ecology Progress Series 29, 280-329. 
Conley, D.J., Humborg, C., Rahm, L., Savchuk, O.P., Wulff, F., 2002. Hypoxia in the Baltic Sea and basin-scale changes in phosphorus biogeochemistry. Environmental Science and Technology 36, 5315-5320.

Conley, D.J., Schelske, C.E., Stoermer, E.F., 1993. Modifications of the biogeochemical cycle of silica with eutrophication. Marine Ecology Progress Series 101, 179-192.

Conley, D.J., Quigley, M.A., 1988. Silica and phosphorus flux from sediments: importance of internal recycling in Lake Michigan. Canadian Journal of Fishery and Aquatic Science 45, 1030-1054.

Cressie, N., Read, T.R., 1985. Do sudden infant deaths come in clusters? Statistics and Decisions 2, 333-349.

Cressie, N., Read, T.R., 1989. Spatial data analysis of regional counts. Biometrics Journal 31, 699-719.

Dahl, O., 2006. Coastally trapped waves and currents. PhD Thesis, Department of Oceanography, Earth Science Centre, University of Gothenburg, Sweden, 24 pp. ISSN 1400-3813.

Danielsson, Å, Rahm, L., Conley, D., Carstensen, J., 2004. Identification of characteristic regions and representative stations: a study of water quality variables in the Kattegat. Environmental Monitoring and Assessment 90, 203-224.

Eilola, K., Stigebrandt, A., 1998. Spreading of juvenile freshwater in the Baltic Proper. Journal of Geophysical Research 103, $27795-27807$.

Finni, T., Kononen, K., Olsonen, R., Wallsröm, K., 2001. The history of cyanobacteria blooms in the Baltic Sea. Ambio 30, 172-178.

Gidhagen, L., 1987. Coastal upwelling in the Baltic Sea e satellite and in situ measurements of sea-surface temperatures indicating coastal upwelling. Estuarine, Coastal and Shelf Science 24, 449-462.

Granat, L., 2001. Deposition of nitrate and ammonium from the atmosphere to the Baltic Sea. In: Wulff, F., Rahm, L., Larsson, P. (Eds.), A Systems Analysis of the Baltic Sea. Ecological Studies. Springer Verlag, pp. 133-148.

Granéli, E.,Wallstro“m, K., Larsson, U., Granéli,W., Elmgren, R., 1990. Nutrient limitation of primary production in the Baltic Sea area. Ambio 19, 142-151.

Grimvall, A., Stålnacke, P., 2001. Riverine inputs of nutrients to the Baltic Sea. In: Wulff, F., Rahm, L., Larsson, P. (Eds.), A Systems Analysis of the Baltic Sea. Ecological Studies. Springer Verlag, pp. 113131.

Håkansson, B., Alenius, P., Brydsten, L., 1996. Physical environment in the Gulf of Bothnia. Ambio Special Report 8, 5-12.

HELCOM, 1998. The third Baltic Sea pollution load compilation. In: Baltic Sea Environment Proceedings No. 70. Helsinki Commission, Helsinki, p. 134.

Humborg, C., Conley, D., Rahm, L., Wulff, F., Cociasu, A., Ittekkot, V., 2000. Silica retention in river basins: far-reaching effects on biogeochemistry and aquatic food webs in coastal marine environments. Ambio 29, 45-50.

Jo“nsson, A., Broman, B., Rahm, L., 2002. Variations in the Baltic Sea wave fields. Ocean Engineering 30, 107126.

Kahru, M., Horstmann, U., Rud, O., 1994. Satellite detection of increased cyanobacteria blooms in the Baltic Sea: natural fluctuation or ecosystem change? Ambio 23, 469-472.

Larsson, U., Hajdu, S., Walve, J., Elmgren, R., 2001. Baltic Sea nitrogen fixation estimated from the summer increase in upper mixed layer total nitrogen. Limnology and Oceanography 46, 811-820.

Larsson, U., Elmgren, R., Wulff, F., 1985. Eutrophication and the Baltic Sea. Ambio 14, 9-14.

Löfgren, S., Gustafson, A., Steineck, S., Stålnacke, P., 1999. Agricultural development and nutrient flows in the Baltic States and Sweden after 1988. Ambio 28, 320-327.

Nehring, D., Mattäus, W., 1991. Current trends in hydrographic and chemical parameters and eutrophication in the Baltic Sea. Internationale Revue der Gesamten Hydrobiologie 76, 297-316.

Nixon, S.W., Ammerman, J.W., Atkinson, L.P., Berounsky, V.M., Billen, G., Boicourt, W.C., Boynton, W.R., Church, T.M., Ditoro, D.M., Elmgren, R., Garber, J.H., Giblin, A.E., Jahnke, R.A., Owens, N.J.P., Pilson, M.E.W.Q., Seitzinger, S.P., 1996. The fate of nitrogen and phosphorus at the land-sea margin of the North Atlantic Ocean. Biogeochemistry 35, 141-180.

Okubo, A., 1971. Oceanic diffusion diagrams. Deep Sea Research 18, 789-802.

Palmén, E., 1930. Untersuchungen über die Strömungen in den Finland ungebenden Meeren. Commentationes Physico-Mathematicae. Societas Scientiarum Fennicae 5, 1-94.

Papush, L., Danielsson, $\AA$., 2006. Silicon in the marine environment: dissolved silica trends in the Baltic Sea. Estuarine, Coastal and Shelf Science 67, 53-66.

Pers, C., Rahm, L., 2000. Changes in apparent oxygen removal in the Baltic Proper deep water. Journal of Marine Systems 25, 421-429.

Rahm, L., Jönsson, A., Wulff, F., 2000. Nitrogen fixation in the Baltic Proper: an empirical study. Journal of Marine Systems 25, 239-248.

Sandén, P., Rahm, L., Wulff, F., 1991. Non-parametric trend test of Baltic Sea data. Environmetrics 2, $263-278$.

Sandén, P., Rahm, L., 1993. Nutrient trends in the Baltic Sea. Environmetrics 4, 75-103. 
Sandén, P., Danielsson, Å ., 1995. Spatial properties of nutrient concentrations in the Baltic Sea. Environmental Monitoring and Assessment 34, 289-307.

Savage, C., 2005. Tracing the influence of sewage nitrogen in a coastal ecosystem using stable nitrogen isotopes. Ambio 34, 145-150.

Savchuk, O., Wulff, F., 1999. Modelling regional and large-scale response of Baltic Sea ecosystems to nutrient load reductions. Hydrobiologia 393, 35-43.

Schelske, C.L., Stoermer, E.F., Conley, D.J., Robbins, J.A., Glover, R., 1983. Early eutrophication in the lower Great Lakes: new evidence from biogenic silica in sediments. Science 222, 320-322.

Sokolov, A.V., Andrejev, O.A., Wulff, F., Rodriguez-Medina, M., 1997. The Data Assimilation System for Data Analysis in the Baltic Sea. In: Ecology Contributions, vol. 3. Stockholm University, 66 pp.

Stålnacke, P., 1996. Nutrient loads to the Baltic Sea. Doctoral Thesis, Department of Water and Environmental Studies, Linköping University, Linköping Studies in Arts and Science No. 146, 78 pp.

Stålnacke, P., Grimvall, A., Libiseller, C., Laznik, M.,Kokorite, L., 2003. Trends in nutrient concentrations in Latvian rivers and the response to the dramatic change in agriculture. Journal of Hydrology 283, 184205.

Stepanauskas, R., Jørgensen, N.O.G., Eigaard, O.R., Zavikas, A., Tranvik, L.J., Leonardson, L., 2002. Summer inputs of riverine nutrients to the Baltic Sea: bioavailability and eutrophication relevance. Ecological Monographs 72, 579-597.

Sweitzer, J., Langaas, C., Folke, C., 1996. Land cover and population density in the Baltic Sea drainage basin: a GIS database. Ambio 25, 191-198.

Voss, M., Liskow, I., Pastuszak, M., Ruß, D., Schulte, D., Dippner, J.W., 2005a. Riverine discharge into a coastal bay: a stable isotope study in the Gulf of Gdansk, Baltic Sea. Journal of Marine Systems 57, 127145.

Voss, M., Emeis, K.-C., Hille, S., Neumann, T., Dippner, J.W., 2005b. Nitrogen cycle of the Baltic Sea from an isotopic perspective. Global Biogeochemical Cycles, doi:10.1029/2004GB002338.

Wulff, F., Rahm, L., Hallin, A.-K., Sandberg, J., 2001. A nutrient budget model of the Baltic Sea. In: Wulff, F., Rahm, L., Larsson, P. (Eds.), A Systems Analysis of the Baltic Sea. Ecological Studies. Springer Verlag, pp. 353-372. 